\title{
Economic Comparison of Recycling Over-Ordered Fresh Concrete: A Case Study Approach
}

\author{
Vivian W. Y. Tam ${ }^{1} *$ and C. M. Tam ${ }^{2}$
}

\begin{abstract}
Recycling of construction material helps save the limited landfill space. Among various types of materials, concrete waste accounts of about $50 \%$ of the total waste generation. Current off-site practices for ready mixed concrete batching plant generate a significant quantity of fresh concrete waste through over-order from construction sites. The use of concrete reclaimer is one of the methods to reclaim these concrete waste, which separates coarse aggregate, sand and cement from fresh concrete. Although there are some concrete producers in Hong Kong providing concrete reclaimers in their plants, they are only used to flush and dilute the cement slurry from the concrete, which will still be sltimately send all to dumping areas. The reluctance of most concrete producers in reclaiming aggregate from the concrete waste is due to its high cost of treatment and lack of space around the plant. Therefore, this paper puts forth a scheme of economical considerations in recycling over-ordered concrete by concrete reclaimer. A comparative study on costs and benefits between the current practices and the proposed recycling plan is examined. The study shows that the costs of the current practices in dumping over-ordered fresh concrete waste to landfill areas are double that of the proposed aggregate recycling plan. Therefore, the adoption of concrete reclaimer in recycling the over-ordered fresh concrete can provide a cost-effective method for the construction industry and help saving the environment.
\end{abstract}

Keywords: Benefit, cost, recycling, concrete, concrete reclaimer, construction

\footnotetext{
${ }^{1 *}$ Corresponding author, Griffith School of Engineering, Griffith University, PMB 50 Gold Coast Mail Centre, QLD 9726, Australia. Tel: (61) 7 -5552-9278; Fax: (61) 7-5552-8065; Email: v.tam@griffith.edu.au

${ }^{2}$ Department of Building \& Construction, City University of Hong Kong, 83 Tat Chee Avenue, Kowloon, Hong Kong.
} 


\section{Introduction}

The comprehensive redevelopment plan proposed by the Urban Renewal Authority, the Hong Kong Special Administrative Region (HKSAR) (Urban Renewal Authority, 2003), embracing 13 areas for redevelopment, coupled with the massive public housing development programme, and the major infrastructure projects in Hong Kong will definitely result in a large amount of construction and demolition (C\&D) waste. The C\&D waste currently accounts for about $38 \%$ of the total waste from the whole community in Hong Kong. Among these C\&D waste, concrete forms the major ingredient. In the United Kingdom and Denmark (Hendriks and Pietersen, 2000, Mulheron, 1988), concrete waste accounts for about 50 to 55\%. In Hong Kong, about $53.1 \%$ and about $48 \%$ of the total C\&D waste is of reinforced concrete and plain concrete generated from demolition and roadwork activities respectively (Civil Engineering Department, 1998, Environmental Protection Department, 2006). The high waste levels of raw materials, inefficient waste management policies and low awareness on waste reduction in Hong Kong lead to these excessive solid waste.

As sustainability in construction is a pressing issue all over the world, the word "recycle" forms one of the most important keywords today (Kawano, 1995). Recycling and resource saving become important, but the effectiveness of their application has been constrained mainly because the conditions in applying these approaches were not provided (Kawano, 1995). These conditions include site space and equipment for waste sorting, experience in waste recycling operations, trained supervisors and employees, knowledge of secondary materials markets, and most importantly, the ignorance of the economic benefits of the recycling schemes. 
Recycling concrete waste is one of the best options. Within the various categories of concrete waste, over-order of concrete is found to be the major contributor among others. Currently, the practice of managing over-ordered fresh concrete is to dump them into landfill areas. The cost for this will be high when the proposed landfill charging scheme in Hong Kong is implemented. Therefore, this paper aims to look into the following:

i) Investigating the situation of C\&D waste in Hong Kong;

ii) Examining the reasons for the generation of concrete waste;

iii) Proposing a recycling plan for recycling over-ordered concrete; and

iv) Providing a cost and benefit analysis on the proposing recycling scheme from the perspective of a concrete batching plant.

\section{Construction and Demolition Waste}

Since 1998, forecasts of C\&D waste have been monitored by the Environmental Protection Department (EPD) of HKSAR, which oversees the management of public fills; the trend is shown in Figure 1. The estimated quantities of $C \& D$ waste are based on the assumption that about $80 \%$ of the total C\&D materials will be delivered to public filling areas and the remaining about 20\% to landfills (Environmental Protection Department, 2006) (Landfills are designed to receive non-inert solid waste from domestic, commercial, and industrial generation while public filling areas for land reclamation and site formation only accept inert materials such as rubble, stone, bricks, concrete from construction and demolition works.)

$<$ Figure $1>$

According to the growing trend of C\&D waste in Figure 1, with about 24\% of annual increase, to be disposed of to landfill from 1991 to 2016, it is necessary to reduce the landfill 
consumption; otherwise, the landfills sites will be running out of in the next ten years (Environmental Protection Department, 2006).

\section{Concrete Waste from Construction Activities}

Li's studies (Li, 2002) attributed that some materials disposed of at landfills were in fact recyclable. The non-recyclable construction waste form a large portion of the waste collected, in which about 4117, 3928, 4259 and 3975 tons are collected from construction sites, demolition sites, general civil works and renovation works respectively. Concrete is the most significant element among all, apportioning up to three quarters, bearing the highest potential in the reduction of material waste.

Regarding the huge generation of concrete waste, five major causes are identified, including (Cheung, 1993, Poon et al., 2001, Poon et al., 2001, Shen and Tam, 2002): i) over ordering; ii) damage during transportation; iii) loss during installation; iv) poor workmanship; and v) change of design. In order to examine the seriousness of these causes, this study has conducted a structured interview to thirty-one construction senior practitioners to collect their opinions. The nomenclature of these practitioners includes senior project managers, project managers, architects, senior quantity surveyors and engineers, with about 15 to 25 years on-site experience. Five levels of responses are collected and the results are summarized as in Table 1.

$<$ Table $1>$

From the interview results shown in Table 1, it can clearly point out that the problem from "over-order" is most serious with an average value of about 3.65. From the current on-site practices, it is unavoidable to over-order ready mixed concrete due to the uncertainty in the 
exact quantity of concrete required. Therefore, a concrete batching plant will, at the end of each working day, receive a huge amount of over-ordered fresh concrete back from the various construction sites, of which they are now being classified as waste and dumped into the landfills.

\section{Existing Practice of Excess Concrete Disposal and Use}

It should be noted that it is nearly impossible to order the exact amount of concrete material required by projects. Normally, on-site quantity surveyors allow about 10 percent more of the estimated concrete material required for the project, because of volume reduction during compaction, and waste during transportation and placing. The most common method to handle the excess concrete material or over-ordered concrete is to dispose them to landfill areas. Construction organizations first place the excess concrete material to a particular place on site until hardened after 24 hours, employees will then remove it and dispose it to landfill areas. It is clear that this method is double handling and therefore it is not very efficient. However, the project's on-site quantity surveyors are necessary to add about 10 percent more of the estimated concrete material to ensure enough concrete material for the project.

To reduce waste generated from the excess concrete material, construction organizations use the following methods: i) to reduce margin percentage from about 10 percent to 5 percent more of the estimated concrete material, depending on different site conditions; ii) to use the excess concrete material for other concrete usage such as leveling pavement; and iii) to provide training programs for frontline workers to use more effectively in concrete material.

\section{Cost and Benefit Analysis}


These over-ordered ready mixed concrete constitutes a significant quantity of fresh concrete waste. From the interview described above and a discussion with the representative of a large concrete batching plant in Hong Kong, it concludes that the average waste level due purely to over-order is about 1.5 percent of the total quantities, representing a serious problem when compared with waste from other causes such as damage during transportation, loss during installation, poor workmanship and change of design.

Currently, the over-ordered fresh concrete is sent back to the batching plant in where they will be flushed and diluted, then broken and dumped to landfill areas when hardened. The disposal costs will be high when the proposed landfill charging scheme is implemented. Further, it is very damaging to the environment.

Concrete reclaimer can reclaim the fresh concrete waste by separating it into coarse aggregate (recyclable element); sand and cement with a sedimentation tank for treating the waste water (see Figure 2). Although there are some concrete producers providing concrete reclaimer in their plants, they are only used currently to separate the large solid waste (coarse aggregate) from the cement slurry and sand, which will all be sent to dumping areas subsequently. The major deterrent in reclaiming the aggregate is the high cost of treatment and space required.

$<$ Figure 2>

The reclaimed coarse aggregate can in fact be used for new construction works in where they can be as competitive as virgin aggregate. The cost saved from the reclaimed aggregate and the landfill charging scheme is worth to be studied. A cost-benefit analysis on the proposed aggregate recycling scheme and the current practice in managing over-ordered fresh concrete is examined. 


\subsection{Aggregate Waste as a Result of Over-Ordered Fresh Concrete}

From the information collected through the discussion with the representative of a concrete batching plant, the common concrete production capacity for a batching plant in Hong Kong is estimated to be about $1,300 \mathrm{~m}^{3}$ (average) and about $2,300 \mathrm{~m}^{3}$ (maximum) of fresh concrete per day, meaning about $474,500 \mathrm{~m}^{3}$ (average) and about $839,500 \mathrm{~m}^{3}$ (maximum) per year. As a result, about $7,117.5 \mathrm{~m}^{3}$ (average) and about $12,592.5 \mathrm{~m}^{3}$ (maximum) of fresh concrete are wasted due to over-order in one batching plant each year. The Government has recently endorsed the landfill charging proposal, which is expected to be in force next year. The charge of disposal to landfill will be set at about HK\$125 per tons (or US\$16) (Environmental Protection Department, 2006). Concrete waste is composed of about $91.67 \%$ solid and about $8.33 \%$ of liquid which will be drained away or evaporated; i.e. about 2,200 out of 2,400 tons is of solid waste. Hence, about 15,659 tons (average) and about 27,704 tons (maximum) of concrete solid waste are disposed to landfills, costing about HK\$1,957,313 (or US\$250,938) (average) and about HK\$3,462,938 (or US\$443,966) (maximum) per year.

Annual over-ordered solid concrete waste:

Average quantity $=474,500 \mathrm{~m}^{3} \times 1.5 \% \times 2.4 \mathrm{ton} / \mathrm{m}^{3} \times 91.67 \%=15,659$ tons

Maximum quantity $=839,500 \mathrm{~m}^{3} \times 1.5 \%$ x $2.4 \mathrm{ton} / \mathrm{m}^{3} \times 91.67 \%=27,704$ tons

Annual landfill charge:

Average value $=15,659$ tons $\mathrm{x} H \mathrm{HK} \$ 125 /$ ton (or US\$16/ton) $=\mathrm{HK} \$ 1,957,313$ (or US\$250,938)

Maximum value $=27,704$ tons $\mathrm{x}$ HK\$125/ton (or US\$16/ton) $=H K \$ 3,462,938$ (or US\$443,966) 
Other than the landfill charges, it also requires to provide labour and water for handling, flushing and diluting concrete and transportation cost of concrete waste to landfills, which also form the major cost elements. Summing up these cost factors, total disposal costs of about HK\$3,796,911 (or US\$486,783) (average) and about HK\$6,717,611 (or US\$861,232) (maximum) are required annually for each batching plant. In the future, it is expected that the government will gradually increase the landfill dumping charge to fully reclaim the service costs, a total cost of about HK\$900 (or US\$115) per ton as stated in EPD (Environmental Protection Department, 2006).

\subsection{Proposed Recycling Scheme}

The fresh concrete waste, before allowed to set, lends itself ideally to being recycled. By doing this, it can reclaim coarse aggregate, sand and water by a concrete reclaimer. This recycling process needs provide sufficient space available to accommodate a concrete reclaimer within the concrete batching plant, without affecting the concrete producing operations. Based on a trial process in a concrete batching plant, it is estimated about $42 \%$, with about 1,000 tons out of 2,400 tons, can be recycled as coarse aggregate from the concrete waste. As stated in EPD (Environmental Protection Department, 2006), to recoup the total service cost of landfill, the total charge needs to be about HK\$900 (or US\$115). As about HK\$125 (or US\$16) is being proposed, an additional cost of about HK\$775 (or US\$99) per ton is required. Further, coarse aggregate is now selling at a price of about HK\$40 (US\$5) per ton. Therefore, a total of about $\mathrm{HK} \$ 5,317,366$ (or US\$681,714) (average) and about HK\$9,407,647 (or US\$1,206,109) (maximum) can be saved by the proposed recycling plan.

Annual benefit from the proposed recycling plan: 
Average benefit $=15,659$ tons $\mathrm{x} 42 \% \mathrm{x}(\mathrm{HK} \$ 40 /$ ton $(\mathrm{US} \$ 5 /$ ton $)+\mathrm{HK} \$ 775 /$ ton (or US\$99/ton)) $=$ HK\$5,317,366 (or US\$681,714)

Maximum benefit $=27,704$ tons $\mathrm{x} 42 \% \mathrm{x}(\mathrm{HK} \$ 40 /$ ton $(\mathrm{US} \$ 5 /$ ton $)+\mathrm{HK} \$ 775 /$ ton (or US\$99/ton)) = HK\$9,407,647 (or US\$1,206,109)

As regards the costs of a concrete reclaimer and a sedimentation tank, assuming about $30 \%$ of capital costs are the annual costs, including about $10 \%$ for capital depreciation, about $10 \%$ for maintenance cost and about $10 \%$ for running cost, about HK\$158,835 (or US\$20,363) and about HK\$39,716 (or US\$5,092) are required as the annual cost of the concrete reclaimer and the sedimentation tanks respectively. Total costs of about HK\$1,840,118 (or US\$235,913) (average) and about HK\$3,102,863 (or US\$397,803) (maximum) will be required in the adoption of the new practice to reclaim the over-ordered fresh concrete waste.

\subsection{Comparative Study}

By comparing the costs of the current and new practices, the new approach can save about HK\$1,956,792 (or US\$250,871) (average) and about HK\$3,614,749 (or US\$463,429) (maximum) annually per batching plant. When all the benefits of the new practice are included (i.e. the total landfill charges and the reuse of recycled aggregate), the new scheme can save about HK\$3,477,247 (or US\$ 445,801) (average) and about HK\$6,304,784 (or US\$808,306) (maximum) per year. Therefore, it can be concluded that the adoption of concrete reclaimer for reclaiming the over-ordered fresh concrete is cost-effective for concrete batching plants in Hong Kong that also helps protect the environment. Summaries of the proposed aggregate recycling plan for the scenarios of average and maximum quantities for a concrete batching plant are tabulated in Tables 2 and 3 respectively. 


\section{Conclusion}

The unacceptable generation of construction waste in Hong Kong has reached a state that a warning signal is flicking as reflected from the running out of landfill areas. One of the best ways to manage this acute environmental problem is by recycling construction waste. As concrete waste forms the major source of construction solid waste, which contributes to about $50 \%$ of total C\&D waste, recycling the concrete waste is the best option to mitigate quantities of construction waste. From the various causes of concrete waste, over-order is found to be most serious. This paper has studied the benefits and costs on the current concrete waste management practice and the proposed aggregate recycling scheme. With the advent of the proposed landfill charging scheme and the costs of the current practice, it is found that the proposed aggregate recycling scheme can result in a huge sum of savings. The benefits gained from the recycling plan can balance the cost expended for the current on-site practice. Therefore, recycling the over-ordered fresh concrete waste by concrete reclaimer provides a cost-effective method for concrete batching plants that also helps protect the environment and achieve construction sustainability.

\section{Acknowledgments}

The work described in this paper was fully supported by a grant from the Housing Authority Research Fund of the Hong Kong Special Administrative Region, China (Project Ref. No. 9460004).

\section{References}

Boerger Pumps Asia Pe Limited, 2004 http://www.wba-tanks.de. 
Civil Engineering Department, 1998 Final report for the review of the public filling strategy and programme. Civil Engineering Department, Mouchel Asia Limited.

Environmental Protection Department, 2006 http://www.info.gov.hk/epd.

Environmental Transport and Works Bureau, 2006 http://www.wb.gov.hk.

Hendriks, CF and Pietersen, HS, 2000 Sustainable raw materials: construction and demolition waste. RILEM Publication.

Henry Manufacturing Company, 2004 http://www.concretecyclone.com.

Kawano, H, 1995. The state of reuse of demolished concrete in Japan, Integrated design and environmental issues in concrete technology: proceedings of the International Workshop 'Rational Design of Concrete Structures under Severe Conditions', Hakodate, Japan, 243-249.

Legislative Council, 2004 http://www.legco.gov.hk.

Poon, CS, Yu, TW and Ng, LH, 2001 A guide for managing and minimizing building and demolition waste. The Hong Kong Polytechnic University.

Poon, CS, Yu, TW and Ng, LH, 2001 On-site sorting of construction and demolition waste in Hong Kong.Resources, Conservation and Recycling 32, 157-172.

Shen, LY and Tam, WYV, 2002 Implementing of environmental management in the Hong Kong construction industry.International Journal of Project Management 20(7), 535-543.

Solid Liquid Separation Technology, 2004

http://www.wamgroup.com/technicalcatalogues/pdfdep/CONSEP_0301.pdf\#search='S olid\%20Liquid\%20Separation\%20Technology\%20concrete\%20reclaimer'.

Urban Renewal Authority, 2003 http://www.ura.org.hk.

Water Supplies Department, 2004 http://www.info.gov.hk/wsd. 
Table 1: Response on reasons leading to waste for concrete activities

\begin{tabular}{|c|c|c|c|c|c|c|c|}
\hline \multirow[t]{2}{*}{ Trade } & \multirow[t]{2}{*}{ Causes } & \multicolumn{5}{|c|}{ Interviewees’ Response } & \multirow[t]{2}{*}{ Mean } \\
\hline & & $\begin{array}{c}\text { Least } \\
\text { significant } \\
\text { “1” }\end{array}$ & $\begin{array}{c}\text { Fairly } \\
\text { significant } \\
\text { "2"? }\end{array}$ & $\begin{array}{c}\text { Significant } \\
\text { “3” }\end{array}$ & $\begin{array}{c}\text { Very } \\
\text { significant } \\
\text { “4” }\end{array}$ & $\begin{array}{c}\text { Extremely } \\
\text { significant } \\
\text { "5” }\end{array}$ & \\
\hline \multirow[t]{5}{*}{ Concrete } & Over-order & $10 \%$ & $10 \%$ & $15 \%$ & $35 \%$ & $30 \%$ & 3.65 \\
\hline & $\begin{array}{l}\text { Damage during } \\
\text { transportation }\end{array}$ & $20 \%$ & $35 \%$ & $10 \%$ & $10 \%$ & $25 \%$ & 2.85 \\
\hline & $\begin{array}{l}\text { Loss during } \\
\text { installation }\end{array}$ & $20 \%$ & $25 \%$ & $20 \%$ & $10 \%$ & $25 \%$ & 2.95 \\
\hline & $\begin{array}{l}\text { Poor } \\
\text { workmanship }\end{array}$ & $15 \%$ & $15 \%$ & $15 \%$ & $10 \%$ & $45 \%$ & 3.55 \\
\hline & Change of design & $40 \%$ & $20 \%$ & $15 \%$ & $13 \%$ & $12 \%$ & 2.37 \\
\hline
\end{tabular}


Table 2: Summary on the proposed recycling plan for a concrete batching plant (on an average quantity)

\begin{tabular}{|c|c|c|c|c|c|c|c|c|}
\hline Recycling plan & \multicolumn{2}{|c|}{ Aggregate waste as a result of over-order concrete } & Amount & \multicolumn{2}{|c|}{$\begin{array}{l}\text { Reuse of aggregate resulted from } \\
\text { over-order concrete }\end{array}$} & Amount & \multicolumn{2}{|l|}{ Remarks } \\
\hline \multicolumn{9}{|l|}{ Benefit } \\
\hline Reuse of aggregate & \multirow{2}{*}{\multicolumn{3}{|c|}{-}} & 6,524 tons & \multirow{2}{*}{$\begin{array}{l}\text { [*around } 42 \%(1000 / 2400) \\
\text { can be recycled as } \\
\text { aggregate from the total } \\
\text { concrete waste] }\end{array}$} & $\begin{array}{l}\text { HK\$260,975 } \\
\text { (or US\$33,458) }\end{array}$ & *Cost of aggregate: & $\begin{array}{l}\text { HK\$40 } \\
\text { (or US\$5) } \\
\text { per ton }\end{array}$ \\
\hline $\begin{array}{l}\text { Recoup the waste treatment } \\
\text { cost and extend the landfill } \\
\text { life }\end{array}$ & & & & 6,524 tons & & $\begin{array}{l}\text { HK\$5,056,391 } \\
\text { (or US\$648,255) }\end{array}$ & $\begin{array}{c}\text { To recoup the cost of landfill, } \\
\text { additional cost per ton (Legislative } \\
\text { Council, 2004) }\end{array}$ & $\begin{array}{l}\text { HK\$775 } \\
\text { (or US\$99) } \\
\text { per ton }\end{array}$ \\
\hline Total Benefit & & (A) & HK\$0 (US\$0) & & (B) & $\begin{array}{c}\mathrm{HK} \$ 5,317,366 \\
\text { (or US\$681,714) }\end{array}$ & & \\
\hline \multicolumn{9}{|l|}{ Cost } \\
\hline $\begin{array}{l}\text { Labour cost for handling, } \\
\text { flushing and diluting cement } \\
\text { from concrete }\end{array}$ & 12,812 man-hours & (*assume 1.8 man-hours $/ \mathrm{m}^{3}$ ) & $\begin{array}{c}\text { HK\$964,065 } \\
\text { (or US\$123,598) }\end{array}$ & 156 man-hours & $\begin{array}{c}0.76 \mathrm{~m}^{3} / 60 \text { s (Henry } \\
\text { Manufacturing Company, } \\
\text { 2004) }\end{array}$ & $\begin{array}{l}\text { HK } \$ 11,745 \\
\text { (or US\$1,506) }\end{array}$ & $\begin{array}{c}\text { Labour cost (unskilled) (male) } \\
\text { (Environmental Transport and Works } \\
\text { Bureau, 2006) }\end{array}$ & $\begin{array}{l}\text { HK\$602 } \\
\text { (or US\$77) } \\
\text { per man-day }\end{array}$ \\
\hline $\begin{array}{l}\text { Water cost for flushing and } \\
\text { diluting concrete }\end{array}$ & 13,025,025 litres & $\begin{array}{c}{ }^{*} \text { Water consumption at } \\
\left.1,830 \text { litres } / \mathrm{m}^{3}\right)\end{array}$ & $\begin{array}{c}\text { HK\$92,608 } \\
\text { (or US\$11,873) }\end{array}$ & 5,694,000 litres & $\begin{array}{l}\text { Water consumption at } 800 \\
\text { litres/m3 (Henry } \\
\text { Manufacturing Company, } \\
\text { 2004) } \\
\end{array}$ & $\begin{array}{c}\text { HK } \$ 40,484 \\
\text { (or US } \$ 5,190 \text { ) }\end{array}$ & $\begin{array}{l}\text { Water cost (Water Supplies } \\
\text { Department, 2004) }\end{array}$ & $\begin{array}{l}\text { HK\$7.11 } \\
\text { (or US\$0.9) per } \\
1,000 \text { litres } \\
\end{array}$ \\
\hline Landfill cost & 15,659 tons & $\begin{array}{c}\text { [*around } 91.6 \%(2200 / 2400) \\
\text { is solid waste and charged for } \\
\text { landfill cost] }\end{array}$ & $\begin{array}{l}\text { HK } \$ 1,957,313 \\
\text { (or US\$250,938) }\end{array}$ & 9,082 tons & $\begin{array}{l}\text { (42\% recycled and } 58 \% \text { to } \\
\text { landfill) }\end{array}$ & $\begin{array}{l}\text { HK\$1,135,241 } \\
\text { (or US\$145,544) }\end{array}$ & $\begin{array}{l}\text { Landfill charge (Environmental } \\
\text { Protection Department, 2006) }\end{array}$ & $\begin{array}{l}\text { HK\$125 } \\
\text { (or US\$16) } \\
\text { per ton }\end{array}$ \\
\hline $\begin{array}{l}\text { Transportation cost of } \\
\text { wasted concrete to landfill }\end{array}$ & 1,566 trucks & $\begin{array}{l}\text { (maximum load of } 10 \text { tons } \\
\text { per truck) }\end{array}$ & $\begin{array}{c}\text { HK\$782,925 } \\
\text { (or US\$100,375) }\end{array}$ & 908 trucks & $\begin{array}{l}\text { (maximum load of } 10 \text { tons } \\
\text { per truck) }\end{array}$ & $\begin{array}{l}\text { HK\$454,097 } \\
\text { (or US } \$ 58,218 \text { ) }\end{array}$ & *Cost of dumping truck: & $\begin{array}{l}\text { HK\$500 } \\
\text { (or US\$64) } \\
\text { per trip }\end{array}$ \\
\hline$* *$ Concrete reclaimer & \multirow{2}{*}{\multicolumn{3}{|c|}{-}} & 1 item & \multirow[t]{2}{*}{ (annual cost) } & $\begin{array}{c}\mathrm{HK} \$ 158,835 \\
\text { (or US\$20,364) }\end{array}$ & $\begin{array}{l}\text { Capital cost of concrete reclaimer } \\
\text { (Henry Manufacturing Company, } \\
\text { 2004) }\end{array}$ & $\begin{array}{c}\text { HK\$529,448 } \\
\text { (or US\$67,878) } \\
\text { per item }\end{array}$ \\
\hline$* *$ Sedimentation tank & & & & 1 set & & $\begin{array}{l}\text { HK\$39,716 } \\
\text { (or US\$5,092) }\end{array}$ & \multirow{2}{*}{$\begin{array}{c}\text { Capital cost of } 4 \text { sedimentation tanks, } \\
\text { which included } 4 \text { man-day at } \$ 602 \text { per } \\
\text { man-day and } 8 \mathrm{~m}^{3} \text { of concrete at } 550 \\
\text { per } \mathrm{m}^{3} \text { (Boerger Pumps Asia Pe } \\
\text { Limited, 2004) }\end{array}$} & \multirow{2}{*}{$\begin{array}{c}\text { HK\$132,388 } \\
\text { (or US\$16,973) } \\
\text { per set }\end{array}$} \\
\hline Total Cost & & (C) & $\begin{array}{c}\mathrm{HK} \$ 3,796,911 \\
\text { (or US\$486,783) }\end{array}$ & & (D) & $\begin{array}{l}\text { HK\$1,840,118 (or } \\
\text { US } \$ 235,913 \text { ) }\end{array}$ & & \\
\hline \multirow{2}{*}{\multicolumn{6}{|c|}{$\begin{array}{r}\text { Difference in cost between with and without aggregate recycling (C-D) } \\
\text { Cost and benefit analvsis for the aggregate recycling plan (B-D) }\end{array}$}} & \multicolumn{3}{|c|}{ HK $\$ 1,956,792$ (or US\$250,871) } \\
\hline & & & & & & \multicolumn{3}{|c|}{ HK $\$ 3,477,247$ (or US $\$ 445,801$ ) } \\
\hline
\end{tabular}


Table 3: Summary on the proposed recycling plan for a concrete batching plant (on a maximum quantity)

\begin{tabular}{|c|c|c|c|c|c|c|c|c|}
\hline Recycling plan & \multicolumn{2}{|c|}{ Aggregate waste as a result of over-order concrete } & Amount & \multicolumn{2}{|c|}{$\begin{array}{l}\text { Reuse of aggregate resulted from } \\
\text { over-order concrete }\end{array}$} & Amount & \multicolumn{2}{|l|}{ Remarks } \\
\hline \multicolumn{9}{|l|}{ Benefit } \\
\hline Reuse of aggregate & \multirow{2}{*}{\multicolumn{3}{|c|}{-}} & 11,543 tons & \multirow{2}{*}{$\begin{array}{c}\text { [*around } 42 \%(1000 / 2400) \\
\text { can be recycled as } \\
\text { aggregate from the total } \\
\text { concrete waste] }\end{array}$} & $\begin{array}{c}\text { HK } \$ 461,725 \\
\text { (or US } \$ 59,196 \text { ) }\end{array}$ & *Cost of aggregate: & $\begin{array}{l}\text { HK\$40 } \\
\text { (or US\$5) } \\
\text { per ton }\end{array}$ \\
\hline $\begin{array}{c}\text { Recoup the waste treatment } \\
\text { cost and extend the landfill } \\
\text { life }\end{array}$ & & & & 11,543 tons & & $\begin{array}{c}\text { HK\$8,945,922 } \\
\text { (or US } \$ 1,146,913 \text { ) }\end{array}$ & $\begin{array}{c}\text { To recoup the cost of landfill, } \\
\text { additional cost per ton (Legislative } \\
\text { Council, 2004) }\end{array}$ & $\begin{array}{l}\text { HK\$775 } \\
\text { (or US\$99) } \\
\text { per ton }\end{array}$ \\
\hline Total Benefit & & (A) & HK\$0 (or US\$0) & & (B) & $\begin{array}{c}\text { HK\$9,407,647 } \\
\text { (or US } \$ 1,206,109 \text { ) }\end{array}$ & & \\
\hline \multicolumn{9}{|c|}{ 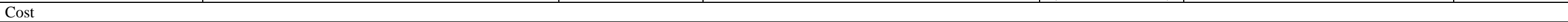 } \\
\hline $\begin{array}{l}\text { Labour cost for handling, } \\
\text { flushing and diluting cement } \\
\text { from concrete }\end{array}$ & 22,667 man-hours & (*assume 1.8 man-hours $/ \mathrm{m}^{3}$ ) & $\begin{array}{l}\text { HK\$1,705,654 } \\
\text { (or US\$218,674) }\end{array}$ & 276 man-hours & $\begin{array}{c}0.76 \mathrm{~m}^{3} / 60 \text { s (Henry } \\
\text { Manufacturing Company, } \\
\text { 2004) }\end{array}$ & $\begin{array}{c}\text { HK\$20,780 } \\
\text { (or US\$2,664) }\end{array}$ & $\begin{array}{c}\text { Labour cost (unskilled) (male) } \\
\text { (Environmental Transport and Works } \\
\text { Bureau, 2006) }\end{array}$ & $\begin{array}{c}\text { HK\$602 } \\
\text { (or US\$77) } \\
\text { per man-day }\end{array}$ \\
\hline $\begin{array}{l}\text { Water cost for flushing and } \\
\text { diluting concrete }\end{array}$ & 23,044,275 litres & $\begin{array}{c}(* \text { Water consumption at } \\
\left.1,830 \text { litres } / \mathrm{m}^{3}\right)\end{array}$ & $\begin{array}{l}\text { HK\$163,845 } \\
\text { (or US } \$ 21,006 \text { ) }\end{array}$ & 10,074,000 litres & $\begin{array}{c}\text { Water consumption at } 800 \\
\text { litres/m3 (Henry } \\
\text { Manufacturing Company, } \\
\text { 2004) } \\
\end{array}$ & $\begin{array}{c}\text { HK\$71,626 } \\
\text { (or US\$9,183) }\end{array}$ & $\begin{array}{l}\text { Water cost (Water Supplies } \\
\text { Department, 2004) }\end{array}$ & $\begin{array}{l}\text { HK\$7.11 } \\
\text { (or US\$0.9) per } \\
1,000 \text { litres } \\
\end{array}$ \\
\hline Landfill cost & 27,704 tons & $\begin{array}{c}\text { [*around } 91.6 \%(2200 / 2400) \\
\text { is solid waste and charged for } \\
\text { landfill cost] }\end{array}$ & $\begin{array}{l}\text { HK\$3,462,938 } \\
\text { (or US\$443,967) }\end{array}$ & 16,068 tons & $\begin{array}{l}\text { (42\% recycled and } 58 \% \text { to } \\
\text { landfill) }\end{array}$ & $\begin{array}{c}\mathrm{HK} \$ 2,008,504 \\
\text { (or US\$257,501) }\end{array}$ & $\begin{array}{l}\text { Landfill charge (Environmental } \\
\text { Protection Department, 2006) }\end{array}$ & $\begin{array}{l}\text { HK\$125 } \\
\text { (or US\$16) } \\
\text { per ton }\end{array}$ \\
\hline $\begin{array}{l}\text { Transportation cost of } \\
\text { wasted concrete to landfill }\end{array}$ & 2,770 trucks & $\begin{array}{c}\text { (maximum load of } 10 \text { tons } \\
\text { per truck) }\end{array}$ & $\begin{array}{l}\text { HK\$1,385,175 } \\
\text { (or US\$177,587) }\end{array}$ & 1,607 trucks & $\begin{array}{c}\text { (maximum load of } 10 \text { tons } \\
\text { per truck) }\end{array}$ & $\begin{array}{c}\mathrm{HK} \$ 803,402 \\
\text { (or US } \$ 103,000 \text { ) }\end{array}$ & ${ }^{*}$ Cost of dumping truck: & $\begin{array}{l}\text { HK\$500 } \\
\text { (or US\$64) } \\
\text { per trip }\end{array}$ \\
\hline **Concrete reclaimer & \multirow{2}{*}{\multicolumn{3}{|c|}{-}} & 1 item & \multirow[t]{2}{*}{ (annual cost) } & $\begin{array}{c}\text { HK\$158,835 } \\
\text { (or US\$20,363) }\end{array}$ & $\begin{array}{l}\text { Capital cost of concrete reclaimer } \\
\text { (Henry Manufacturing Company, } \\
\text { 2004) }\end{array}$ & $\begin{array}{l}\text { HK\$158,835 } \\
\text { (or US\$20,363) }\end{array}$ \\
\hline **Sedimentation tank & & & & 1 set & & $\begin{array}{c}\text { HK\$39,716 } \\
\text { (or US\$5,092) } \\
\end{array}$ & \multirow{2}{*}{$\begin{array}{c}\text { Capital cost of } 4 \text { sedimentation tanks, } \\
\text { which included } 4 \text { man-day at } \$ 602 \text { per } \\
\text { man-day and } 8 \mathrm{~m}^{3} \text { of concrete at } 550 \\
\text { per m } \text { m }^{3} \text { (Boerger Pumps Asia Pe } \\
\text { Limited, 2004) }\end{array}$} & \multirow{2}{*}{$\begin{array}{c}\mathrm{HK} \$ 39,716 \\
\text { (or US\$5,092) }\end{array}$} \\
\hline Total Cost & & (C) & $\begin{array}{c}\mathrm{HK} \$ 6,717,611 \\
\text { (or US\$861,232) }\end{array}$ & & (D) & $\begin{array}{c}\mathrm{HK} \$ 3,102,863 \\
\text { (or US\$397,803) }\end{array}$ & & \\
\hline \multirow{2}{*}{\multicolumn{6}{|c|}{$\begin{array}{l}\text { Difference in cost between with and without aggregate recycling (C-D) } \\
\text { Cost and benefit analysis for the aggregate recycling plan (B-D) }\end{array}$}} & \multicolumn{3}{|c|}{$\begin{array}{l}\text { HK\$3,614,749 (or US } \$ 463,429) \\
\text { HK\$6,304 } 784 \text { (or U } \$ 808,306)\end{array}$} \\
\hline & & & & & & \multicolumn{2}{|c|}{ HK $\$ 6,304,784$ (or US $\$ 808,306$ ) } & \\
\hline
\end{tabular}




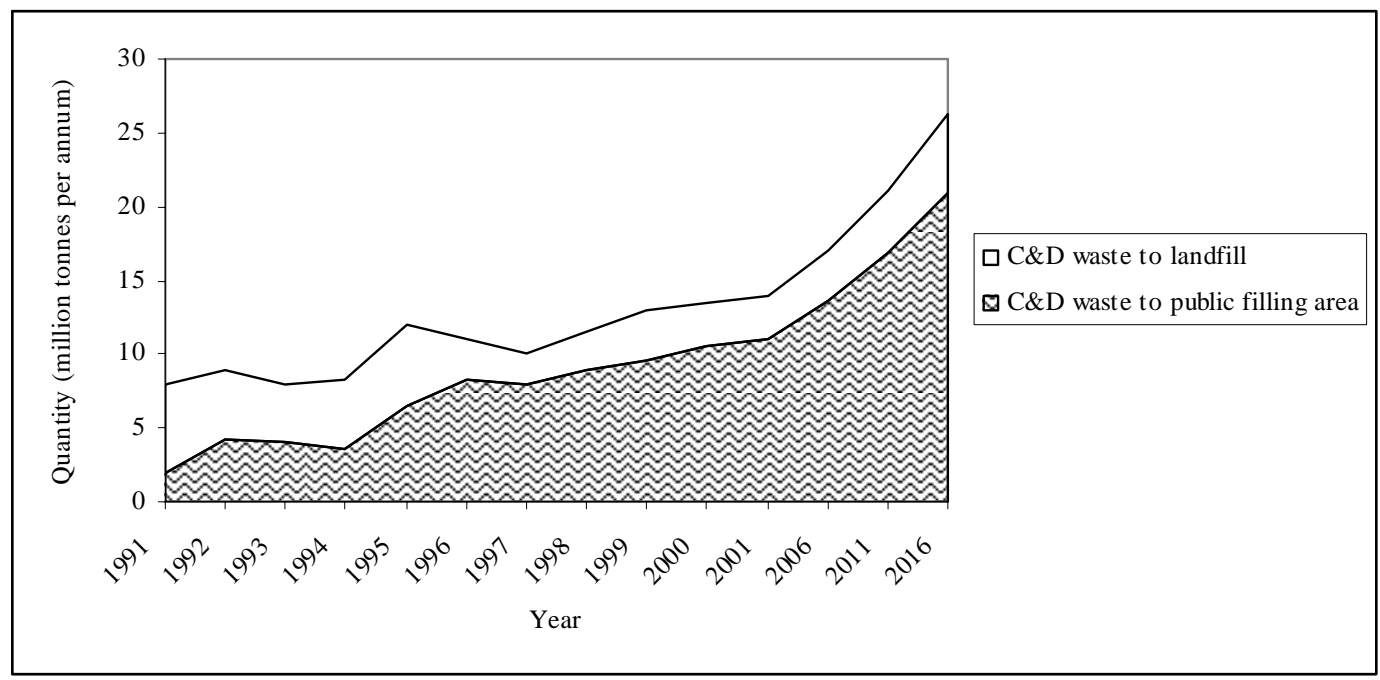

Figure 1: Trend of quantities of construction and demolition waste disposed of at public filling areas and landfills from 1991-2016 (Environmental Protection Department, 2006) 


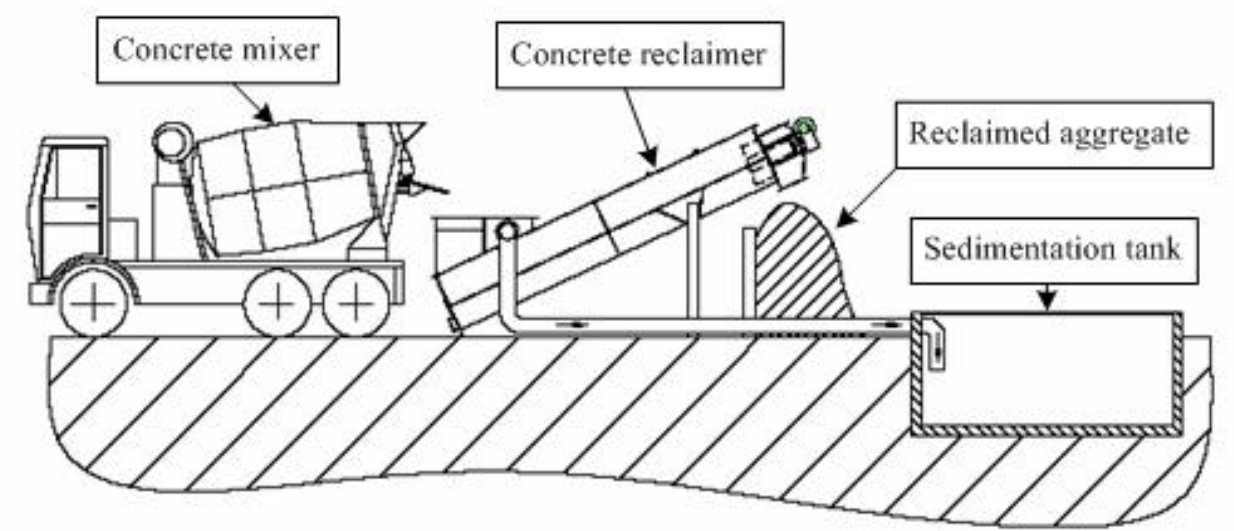

Figure 2: On-site Setting for Concrete Reclaimer and Sedimentation Tank (Solid Liquid Separation Technology, 2004) 